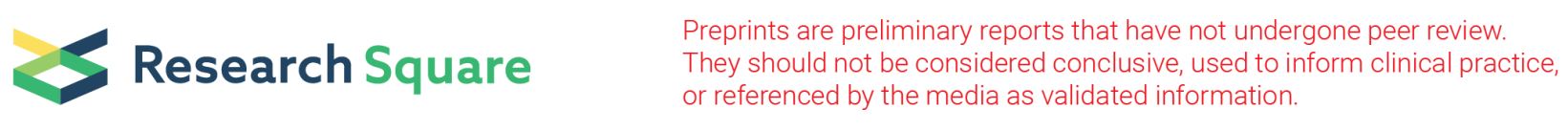

\title{
Hydrogeochemistry and hydrogeology of a fractured urban aquifer in the metropolitan region of Florianópolis, Southern Brazil
}

Crysthian Bernardi ( $\nabla$ crysthianzb@gmail.com )

Universidade Federal do Rio Grande do Sul https://orcid.org/0000-0001-7875-5305

Antonio Pedro Viero

Federal University of Rio Grande do Sul: Universidade Federal do Rio Grande do Sul

Ari Roisenberg

Federal University of Rio Grande do Sul: Universidade Federal do Rio Grande do Sul

\section{Research Article}

Keywords: Fractured Aquifer, Urban aquifer, Hydrogeology, Hydrogeochemistry, Florianopolis, Brazil

Posted Date: March 16th, 2021

DOI: https://doi.org/10.21203/rs.3.rs-213631/v1

License: (1) This work is licensed under a Creative Commons Attribution 4.0 International License. Read Full License 


\section{Abstract}

This paper was carried out through database of hydrogeological information of tubular wells based on the Groundwater Information System (SIAGAS) from the Geological Survey of Brazil (CPRM). The geology of the study area shows two main domains, a complex Crystalline Precambrian Shield partially covered by Quaternary sediments. Two main regional directions of tectonic lineaments were defined using satellite images with NE-SW and NW-SE orientations. The average discharges and specific capacities of the wells show values of $13.1 \mathrm{~m} 3$ $/ \mathrm{h}$ and $0.59 \mathrm{~m} 3 / \mathrm{h} / \mathrm{m}$ respectively. NW-SE linear structures were more productive than NE-SW, however the highest discharge values and the highest average $(15.6 \mathrm{~m} 3 / \mathrm{h})$ are related to abstractions influenced by both directions simultaneously. Serra do Tabuleiro Granite is the lithology with the greatest productive potential in the region, followed by São Pedro de Alcântara Granite and the Granite-Gneiss-Migmatitic Complex. Sodium bicarbonate and calcium bicarbonate waters are the two main hydrochemical groups that occur in the region. The dissolution of calcium carbonate filling the fractures of the rocks is the main source responsible for the alkalinity of the water. The cationic proportion is defined by $\mathrm{Na}+>\mathrm{Ca} 2+>\mathrm{Mg} 2+>\mathrm{K}+$. In some wells, the increasing of Total Dissolved Solids (TDS) is probably related to the contribution of adjacent Quaternary porous aquifers deposited under marine influence.

\section{Introduction}

The hydrogeological and hydrogeochemical studies of the fractured aquifer in the metropolitan region of Florianopolis are scarce. The region has as main economic activities that benefit from the use of groundwater agriculture, industrial and tourism (hotel). Aquifers are also an alternative to rural areas where there is no water supply through public or private companies responsible for water distribution and basic sanitation.

Due to the heterogeneity and anisotropy of crystalline aquifers, hydrogeological studies help with the best locations for drilling tubular wells, while hydrochemical analyzes are essential for evaluations regarding water potability.

Some coastal municipalities, in consequence of the expressive increase of the population in times of high season and/or periods of drought, sometimes suffer scarcity of water for domestic supply since are dependent from watercourses do the catchment. Therefore, knowledge about fractured aquifers is important for the long-term management of groundwater reserves and obtaining sources of water alternative to supplying the population.

Consequently, the present paper aims to discuss the hydrogeology and hydrogeochemical characterization of this urban and fractured aquifer in the metropolitan region of Florianópolis exposing the main reactions that give rise to water chemistry, relating the chemical content to the lithologies present in the region, establishing links between groundwater potential with linear structures and recognizing lithologies and conditions for higher productivity.

\section{Study area and geological setting}

\section{Location}

The study region is located at the coastal area of the Santa Catarina State, Southern Brazil and includes the municipalities of Florianópolis, Palhoça, Santo Amaro da Imperatriz, Águas Mornas, São José, São Pedro de Alcântara, Antônio Carlos, Biguaçu e Governador Celso Ramos (Fig. 1), covering an area about $2.745 \mathrm{~km}^{2}$ with a total population of 1.398 .698 people. The average temperature in the region is of about $19^{\circ} \mathrm{C}$ and the annual precipitation of approximately $1900 \mathrm{~mm}$ (CPRM, 2011).

The crystalline lithologies in this area are located in the Santa Catarina Shield. CPRM (2014) divides this geotectonic unit into four tectonic terrains: Paranaguá, Luís Alves, Tijucas and Florianopolis. The Florianopolis Terrain comprises igneous lithologies related to the Florianopolis Batholith, metasediments of the Queçaba Formation and the metamorphic rocks of the Granite-Gneiss-Migmatitic Unit Águas Mornas. Figure 2 demonstrate the geology of the region and the locations of the wells used to carry out this study.

The Florianopolis Batholith in the region study is composed by eight different igneous lithologies, as shown in the Figure 2: Forquilha Tonalite (ft), Alto da Varginha Granodiorite (avg), Rio das Antas Granite (rag), Angelina Granite (ag), Itacorumbi Granite (itg), São Pedro de Alcântara Granite (spag), Ilha Granite (ig) and Serra do Tabuleiro Granite (stg). The three last ones with larger surface exposures in the area.

The Cambirela Rhyolite (cr) represent a volcanogenic sequence that occur in the Southern portion of the study area, in addition to the metasedimentary sequence. The Águas Mornas Complex (amc) comprises a Granite-Gneiss-Migmatitic association that occupies a large surface area in the West portion inland. The metasedimentary sequence is represented by the Queçaba Formation (qf), that contains quartzites, mica schists, quartz-schists and phyllites. The Agua Mornas Complex constitutes a Granite-Gneiss-Migmatitic Complex, an 
association of polyphasic orthogneisses with paleosomes of basic to intermediate nature (orthoamphibolites, metagabbros, metabasites and metadiorites), quartz-diorites and granodiorites gneisses.

Quaternary deposits of Holocene age occur in restinga bundles fluvio-deltaic marine deposits, tidal flats deposits, eolian deposits, lagoon deposits, colluvium-alluvial deposits, mainly along the coastal area.

\section{Materials And Methods}

The well information used to carry out the paper was static water level (SWL), pumping water level (PWL), discharge, specific capacity, drilling logs and physical-chemical parameters.

Elements for structural analysis were produced using Alos Palsar and Landsat-8 satellite images and the software's Qgis 3.4 and Arcgis 10.5, resulting in Digital Terrain Models (DTM) and a colored RGB composition. The lineaments that intercept the $1.5 \mathrm{~km}$ radius around the wells were mapped at the 1:20.000 and 1:40.000 scales in order to find relationships between directions of linear structures and the well's productivity. From the computational tool AzimuthFinder, added to Arcgis, it was possible to obtain the number of lineaments and their orientations. The rose diagram was produced using the Stereo32 software.

The hydrogeological and hydrogeochemical interpretations were conducted using the well's information combined with the two Gis-software for spatial visualization.

Through the Excel program, spreadsheets were elaborated with the data sets, perform calculations and graph formulation. The hydrochemical groups in the wells were obtained by means of the Qualigraf software (v 1.17).

\section{Results And Discussion}

\section{Hydrogeological Characterization}

Most tubular wells have depths between 50 to 100 meters (42.5\%), while $35 \%$ are 100 to 150 meters deep (Tab. 1).

Table 1 - Hydrogeological data with percentage distribution in relation to the parameters analyzed in the tubular wells. The analysis of the depth of water entries interval demonstrates the amount of wells that contain that range and is greater than the total number of wells analyzed since it is possible to occur more than one interval in a well. The other lithologies that show the occurrence of wells were not obtained discharge averages due to the location of only one well, as shown in figure 3 


\begin{tabular}{|c|c|c|c|c|c|c|}
\hline Parameters & Results & & & & & $\begin{array}{l}\text { Total wells } \\
\text { analyzed }\end{array}$ \\
\hline Well depth (m) & 0 to $50(10 \%)$ & $\begin{array}{l}50 \text { to } 100 \\
(42.5 \%)\end{array}$ & $\begin{array}{l}100 \text { to } 150 \\
(35 \%)\end{array}$ & $\begin{array}{l}150 \text { to } 200 \\
(0 \%)\end{array}$ & $\begin{array}{l}>200 \\
(12.5 \%)\end{array}$ & 40 \\
\hline \multirow[t]{2}{*}{ Number of water entries } & \multirow[t]{2}{*}{$1(37.04 \%)$} & \multirow[t]{2}{*}{$2(22.22 \%)$} & 3 & $>3$ & & \multirow[t]{2}{*}{27} \\
\hline & & & $(18.52 \%)$ & $(22.22 \%)$ & & \\
\hline \multirow[t]{2}{*}{ Depth of water entries (m) } & 0 to 20 & 20 to 50 & 50 to 100 & $>100$ & & \multirow[t]{2}{*}{27} \\
\hline & 4 wells & 19 wells & 11 wells & 2 wells & & \\
\hline \multirow[t]{2}{*}{ SWL (m) } & \multirow[t]{2}{*}{1 to $5(64.1 \%)$} & \multirow{2}{*}{$\begin{array}{l}5 \text { to } 10 \\
(23.07 \%)\end{array}$} & \multirow{2}{*}{$\begin{array}{l}10 \text { to } 20 \\
(2.56 \%)\end{array}$} & $>20$ & & \multirow[t]{2}{*}{39} \\
\hline & & & & $(10.25 \%)$ & & \\
\hline PWL (m) & $\begin{array}{l}1 \text { to } 20 \\
(20.5 \%)\end{array}$ & $\begin{array}{l}20 \text { to } 40 \\
(33.33 \%)\end{array}$ & $\begin{array}{l}40 \text { to } 60 \\
(28.2 \%)\end{array}$ & $\begin{array}{l}>60 \\
(17.94 \%)\end{array}$ & & 39 \\
\hline Drawdown (m) & $\begin{array}{l}1 \text { to } 20 \\
(33.33 \%)\end{array}$ & $\begin{array}{l}20 \text { to } 40 \\
(30.76 \%)\end{array}$ & $\begin{array}{l}40 \text { to } 60 \\
(20.51 \%)\end{array}$ & $\begin{array}{l}>60 \\
(15.38 \%)\end{array}$ & & 39 \\
\hline Discharge $\left(m^{3} / h\right)$ & $\begin{array}{l}0 \text { to } 5 \\
(35.89 \%)\end{array}$ & $\begin{array}{l}5 \text { to } 10 \\
(12.82 \%)\end{array}$ & $\begin{array}{l}10 \text { to } 20 \\
(33.33 \%)\end{array}$ & $\begin{array}{l}>20 \\
(17.94 \%)\end{array}$ & & 39 \\
\hline Specific capacity $\left(\mathrm{m}^{3} / \mathrm{h} / \mathrm{m}\right)$ & $\begin{array}{l}0 \text { to } 0.3 \\
(62.16 \%)\end{array}$ & $\begin{array}{l}0.3 \text { to } 0.5 \\
(8.1 \%)\end{array}$ & $\begin{array}{l}0.5 \text { to } 1.0 \\
(13.51 \%)\end{array}$ & $\begin{array}{l}>1.0 \\
(16.21 \%)\end{array}$ & & 37 \\
\hline \multirow{2}{*}{$\begin{array}{l}\text { Average discharges by } \\
\text { lithologies }\end{array}$} & ig & stg & spag & amc & & \multirow[t]{2}{*}{39} \\
\hline & $7,5 \mathrm{~m}^{3} / \mathrm{h}$ & $18,4 \mathrm{~m}^{3} / \mathrm{h}$ & $17,8 \mathrm{~m}^{3} / \mathrm{h}$ & $17 \mathrm{~m}^{3} / \mathrm{h}$ & & \\
\hline
\end{tabular}

Twenty-seven wells demonstrate information about the water entry in drilling logs. Regarding the quantity of water entries, there is a predominance of only one (1) water entry and, concerning to their depth, there is predominance of water entries in the depth range 20 to 50 meters.

Static water levels vary between 0.8 and 40 meters, with an average value of $6.63 \mathrm{~m}$. The pumping water levels vary between depth of 4.73 and 160 meters with an average of $44.66 \mathrm{~m}$. The highest drawdowns are probably related to low recharge sites and/or more confined areas of the aquifer.

The discharges have a water volume between 1 and $51.2 \mathrm{~m}^{3} / \mathrm{h}$, with an average of $13.1 \mathrm{~m}^{3} / \mathrm{h}$. In most wells the discharge values are between 0 to $5 \mathrm{~m}^{3} / \mathrm{h}$ (35.89\%), followed by a second group with discharges between 10 to $20 \mathrm{~m}^{3} / \mathrm{h}$ (33.33\%), as shown in Table 1 and Figure 3.

In most cases higher discharge values occur in wells with greater amounts of fractures in the lithological profile, but this fact is not considered as a rule, because other factors can interfere in the results, such as spacing of the fractures, degree of fracturing, the connection between fractures and aquifer confinement. These conditions have a direct impact on the hydraulic conductivity, storage capacity and groundwater renewal.

The lithologies do not show uniformity in relation direct relationships to the discharges (Fig. 3), despite the averages having approximate values in three of them (Tab. 1). Well 16, with the highest discharge $\left(51.2 \mathrm{~m}^{3} / \mathrm{h}\right)$, is located in the spag, close to seven other wells $(11,15,17$, $18,19,20$ and 32) within a radius of $6 \mathrm{~km}$. This region is extensively explored from the hydrogeological point of view and demonstrates satisfactory productivity in general.

From the productivity point of view, the northern regions of Palhoça Municipality, and the central West of the municipalities of Santo Amaro da Imperatriz and Águas Mornas were defined as areas with the highest potential for groundwater extraction.

\section{Structural analysis}

Analyzing in the satellite images a uniform distance of $1.5 \mathrm{~km}$ around each well, 396 linear structures were identified. The main directions of lineaments were $\mathrm{N} 30^{\circ}-60^{\circ} \mathrm{E}$ and $\mathrm{N} 20^{\circ}-60^{\circ} \mathrm{W}$ with prevalence of the last ones (Fig. 4). 
Figure 5 shows that when the lineation had only one main direction around the well, the discharges are higher along the NW-SE direction (average $13.6 \mathrm{~m}^{3} / \mathrm{h}$ ) than in the NE-SW direction (average $8.6 \mathrm{~m}^{3} / \mathrm{h}$ ). Nevertheless, some structures NE-SW also present a relatively high discharge (wells 2, 15, 32 and 39). The two most productive wells in the region (well 16 and 24) receive water from both orientations.

\section{Major ion chemistry and source of solutes}

Table 2 demonstrate the minimum, average and maximum concentrations of the main physical-chemical parameters according to the lithologies.

Table 2 - Minimum, maximum and average concentrations referring to physicochemical parameters used in the hydrogeochemical study. Lithologies with only one result for each parameter contain only one well. E.C - Electric Conductivity; TDS = Total Dissolved Solids; ND = Not detected; Asterisk = No data. 


\begin{tabular}{|c|c|c|c|c|c|c|c|c|}
\hline \multicolumn{2}{|c|}{ Parameters/lithology } & ig & $\operatorname{ltg}$ & amc & stg & $\mathrm{cr}$ & spag & $\mathrm{rag} / \mathrm{ft}$ \\
\hline \multirow[t]{3}{*}{$\mathrm{Na}^{+}(\mathrm{mg} / \mathrm{L})$} & Min. & 2 & * & 5.61 & 3.35 & \multirow[t]{3}{*}{176} & 2.9 & \multirow[t]{3}{*}{7.63} \\
\hline & Max. & 71.6 & & 42.5 & 31 & & 33.8 & \\
\hline & Ave. & 17.47 & & 21.56 & 10.04 & & 9.72 & \\
\hline \multirow[t]{3}{*}{$\mathrm{K}^{2+}(\mathrm{mg} / \mathrm{L})$} & Min. & 1,4 & * & 0.5 & 1.95 & \multirow[t]{3}{*}{3,7} & 0.08 & \multirow[t]{3}{*}{1.5} \\
\hline & Max. & 4.12 & & 2.2 & 5.4 & & 2.15 & \\
\hline & Ave. & 2.36 & & 1.28 & 3.49 & & 1.19 & \\
\hline \multirow[t]{3}{*}{$\mathrm{Ca}^{2+}(\mathrm{mg} / \mathrm{L})$} & Min. & 0.18 & * & 3.82 & 0.25 & \multirow[t]{3}{*}{34,87} & 4.8 & \multirow[t]{3}{*}{7.03} \\
\hline & Max. & 44.64 & & 30.4 & 14.51 & & 29.99 & \\
\hline & Ave. & 13.32 & & 15.84 & 5.35 & & 13.17 & \\
\hline \multirow[t]{3}{*}{$\mathrm{Mg}^{2+}(\mathrm{mg} / \mathrm{L})$} & Min. & 0.48 & * & 1.98 & 0.16 & \multirow[t]{3}{*}{10,45} & 1.5 & \multirow[t]{3}{*}{2.32} \\
\hline & Max. & 30.99 & & 14.88 & 1.6 & & 13.55 & \\
\hline & Ave. & 4.9 & & 5.65 & 0.85 & & 4.15 & \\
\hline \multirow[t]{3}{*}{$\mathrm{HCO}_{3}^{-}(\mathrm{mg} / \mathrm{L})$} & Min. & 20.58 & * & 31.2 & 15 & \multirow[t]{3}{*}{193,74} & 39.8 & \multirow[t]{3}{*}{ * } \\
\hline & Max. & 285.72 & & 143 & 109.8 & & 73 & \\
\hline & Ave. & 74.58 & & 87.24 & 56.16 & & 49.06 & \\
\hline \multirow[t]{3}{*}{$\mathrm{SO}_{4}{ }^{2-}(\mathrm{mg} / \mathrm{L})$} & Min. & 1 & * & 1.1 & 0.01 & \multirow[t]{3}{*}{33,09} & 1.2 & \multirow[t]{3}{*}{1.1} \\
\hline & Max. & 25.34 & & 24 & 2.1 & & 18.7 & \\
\hline & Ave. & 4.75 & & 5.91 & 1.10 & & 5.2 & \\
\hline \multirow[t]{3}{*}{$\mathrm{Cl}^{-}(\mathrm{mg} / \mathrm{L})$} & Min. & 4.4 & 24.94 & 3.5 & 1.77 & \multirow[t]{3}{*}{282,95} & 3.84 & \multirow[t]{3}{*}{3} \\
\hline & Max. & 80.27 & & 20 & 5.18 & & 132.72 & \\
\hline & Ave. & 24.77 & & 9.78 & 3.47 & & 28.88 & \\
\hline \multirow{3}{*}{$\mathrm{Fe}^{\top}(\mathrm{mg} / \mathrm{L})$} & Min. & 0.0008 & 4.5 & 0.01 & 0.002 & \multirow[t]{3}{*}{0,36} & 0.01 & \multirow[t]{3}{*}{0.01} \\
\hline & Max. & 2.04 & & 0.2 & 0.21 & & 0.34 & \\
\hline & Ave. & 0.36 & & 0.06 & 0.03 & & 0.08 & \\
\hline $\mathrm{Mn}(\mathrm{mg} / \mathrm{L})$ & Min. & ND & 0.957 & ND & ND & * & 0.001 & 0.001 \\
\hline & Max. & 0.15 & & 0.13 & 0.01 & & 0.22 & \\
\hline & Ave. & 0.03 & & 0.08 & 0.0029 & & 0.04 & \\
\hline $\mathrm{F}^{-}(\mathrm{mg} / \mathrm{L})$ & Min. & 0.01 & * & 0.12 & 0.1 & 6 & 0.07 & 0.14 \\
\hline & Max. & 2.06 & & 0.99 & 2.8 & & 1.84 & \\
\hline & Ave. & 0.57 & & 0.35 & 0.8 & & 0.46 & \\
\hline $\mathrm{NO}_{3}^{-}(\mathrm{mg} / \mathrm{L})$ & Min. & ND & * & ND & 0.27 & ND & ND & 0.9 \\
\hline & Max. & 13.26 & & 15.29 & 1.8 & & 4.87 & \\
\hline & Ave. & 2.35 & & 7.03 & 0.86 & & 1.63 & \\
\hline Silica (mg/L) & Min. & 1.28 & * & 7.34 & 7.44 & 34.99 & 10.32 & 8.98 \\
\hline & Max. & 93.8 & & 25.6 & 45.9 & & 67.64 & \\
\hline & Ave. & 32.27 & & 15.46 & 24.82 & & 42.72 & \\
\hline Alkalinity (mg/L) & Min. & 16 & 79.32 & 79 & 15 & 158,8 & 43.16 & * \\
\hline & Max. & 234.2 & & 143 & 90 & & 152 & \\
\hline
\end{tabular}




\begin{tabular}{|c|c|c|c|c|c|c|c|c|}
\hline & Ave. & 59.6 & & 111 & 54.17 & & 87.01 & \\
\hline \multirow[t]{3}{*}{ E.C $(\mu S / c m)$} & Min. & 70.6 & \multirow[t]{3}{*}{ * } & 86.6 & 41 & \multirow[t]{3}{*}{1107} & 18.54 & \multirow[t]{3}{*}{131} \\
\hline & Max. & 717 & & 196.9 & 620 & & 604.2 & \\
\hline & Ave. & 231.63 & & 163.69 & 209.18 & & 220.28 & \\
\hline \multirow[t]{3}{*}{ TDS (mg/L) } & Min. & 40 & \multirow[t]{3}{*}{182.4} & 98.47 & 22.44 & \multirow[t]{3}{*}{805} & 89 & \multirow[t]{3}{*}{ * } \\
\hline & Max. & 178 & & 128.29 & 142 & & 362 & \\
\hline & Ave. & 113.05 & & 113.38 & 72.48 & & 159 & \\
\hline \multirow[t]{3}{*}{$\mathrm{pH}$} & Min. & 4.9 & \multirow[t]{3}{*}{6.28} & 5.5 & 4.65 & \multirow[t]{3}{*}{7,88} & 6.25 & \multirow[t]{3}{*}{6.22} \\
\hline & Max. & 7.48 & & 7.74 & 7.83 & & 7.5 & \\
\hline & Ave. & 6.26 & & 6.71 & 6.22 & & 6.72 & \\
\hline
\end{tabular}

\section{Sodium, Chloride and Sulfate}

Regarding sodium, three wells (2, 14 and 38) show concentrations with relatively high values above the average in the region (18.79 mg/L). Among this three, well 14 has the highest content with $176 \mathrm{mg} / \mathrm{L}$, which is not usual for fractured aquifers. This well is located close to the sea $(\approx 1.9 \mathrm{~km})$ in the Southern part of the city Palhoça, where there are superficial layers of lagoon sediments, which were deposited under shallow marine influence.

Sodium analyses combined with other parameters of well 14, such as chloride (282 mg/L), sulfate (33.09 mg/L) and the electrical conductivity $(1.107 \mu \mathrm{S} / \mathrm{cm})$ reveals higher concentrations of salts in the water when compared to the averages of these ions in the study area respectively $25.67 \mathrm{mg} / \mathrm{L}, 5.02 \mathrm{mg} / \mathrm{L}$ and $232.77 \mu \mathrm{s} / \mathrm{cm}$. Given the above, the groundwater in this well probably reflect the interaction with Quaternary sediments.

The well 2 has a similar condition, with $71.6 \mathrm{mg} / \mathrm{L}$ of sodium. Again, analysis together with other parameters of this well such as chloride $(80.27 \mathrm{mg} / \mathrm{L})$, sulfate $(25.34 \mathrm{mg} / \mathrm{L})$, and EC $(717 \mu \mathrm{s} / \mathrm{cm})$ shows that water also contains high salt content. In this case, it must be considered that the well is located through a regional linear structure that connects directly to the Praia Brava beach, in the Northern sector of the Florianopolis island. The enterprise that operates the well uses a great volume to maintain a water park, causing water table dropdown by pumping and a probable saline intrusion of marine water. This condition is reinforced by the positive correlation between sodium and chloride in the two mentioned wells (Fig. 6a).

According to Davies \& DeWiest (1966), normally groundwater that percolates through crystalline rocks has low content of chloride, often below $30 \mathrm{mg} / \mathrm{L}$. The wells under analysis are mostly correlated with this statement, excepting the wells 2, 14 and the 16.

The waters of well 16 acquire chloride ions through the silt-clay and sand sediments of the Lagoon Deposit, since the concentration of $132.72 \mathrm{mg} / \mathrm{L}$ of $\mathrm{Cl}$ - is not common in percolating waters in granitic aquifers, the most frequent in the region.

Figure $6 \mathrm{~b}$ shows the positive correlation of sulfate with chloride with the exception of well 27. Given that granite and similar rocks do not have high $\mathrm{Cl}$ - and $\mathrm{SO}_{4}{ }^{2-}$ contents, it is possible to state that most sulfate concentrations have their sources related to chloride sources. As it is a rural area with soil management for agriculture, the use of sulfated fertilizers such as ammonium sulfate and magnesium sulfate, widely used in agriculture, increases the ion content in the well water. Fact corroborated by the greater amount of magnesium in that location: $14.88 \mathrm{mg} / \mathrm{L}$.

\section{Calcium, magnesium and bicarbonate}

Figure 7a and $7 \mathrm{~b}$ shows the positive correlation between calcium, magnesium and bicarbonate, therefore, the source for calcium and magnesium content in the study region is the hydrolysis of calcium carbonate with minor dolomitic fraction that fills the fractures of the aquifer according to reaction 1 .

$\mathrm{CaCO}_{3}+\mathrm{H}_{2} \mathrm{O} \leftrightarrow \mathrm{Ca}^{2+}+\mathrm{HCO}_{3}^{-}+\mathrm{OH}^{-}(1)$ 
Magnesium are in relatively low concentrations in water, excepting in well 2, where achieves de maximum values (30, 99 mg/L). Such a well is drilled in a gabbroic or dolerite rock intruded in the Ilha Granite. In this case, hydrolysis of mafic minerals (olivine, pyroxenes and amphiboles) in the soil horizons can liberate magnesium to water.

Carbonates also occur as alteration minerals in some lithologies where the highest concentrations of calcium in water are observed (Ilha Granite, São Pedro de Alcântara Granite, Alto da Varginha Granodiorite). Silicic minerals containing calcium (plagioclases, pyroxenes and amphiboles), can also contribute to increase calcium content in the water, however, within the crystalline aquifers the contribution is less important, since the rate of hydrolysis is slow (Hem, 1985).

Among the three main anions used to classify groundwater $\left(\mathrm{HCO}_{3}{ }^{-}, \mathrm{SO}_{4}{ }^{2-}\right.$ and $\left.\mathrm{Cl}^{-}\right)$, bicarbonate is predominant in the study area. Igneous rocks normally present this characteristic because they have low content of $\mathrm{Cl}^{-}$and $\mathrm{SO}_{4}{ }^{2-}$ (Appelo; Postma, 2005).

\section{Potassium and silica}

The concentration of potassium in the water samples are relatively low (maximum $=5.4 \mathrm{mg} / \mathrm{L}$ ), resulting from resistance of $\mathrm{K}$-feldspar to hydrolysis in the granitic aquifers. It must be emphasized the intense participation of potassium in ion exchange processes, being easily adsorbed by clay minerals and hardly removed by hydrolysis from its structure.

Silica is a minor compound in groundwater, being liberated to water during hydrolysis of silicate minerals contained in the granitic aquifer. According to Hem et al. (1963), the groundwater that percolates in granitic rocks, usually presents silica concentrations between 15 and 75 $\mathrm{mg} / \mathrm{L}$.

\section{Fluoride}

The fluoride contents in water range from 0.01 to $2.8 \mathrm{mg} / \mathrm{L}$ in most cases, excepting in well 14 (6,0 mg/L). High concentrations of fluoride is a common potability restriction for water, considering the maximum value establish by the WHO (1.5 mg/L). The main source for fluoride in the aquifers is fluorite, a common accessory mineral in granites, but also frequent as veins cutting the host granitic or gneissic rock. The dissolution process of fluorite follows the reaction 2 :

$\mathrm{CaF}_{2} \leftrightarrow \mathrm{Ca}^{2+}+2 \mathrm{~F}^{-}(2)$

In the specific case of well 14, the geological profile shows a thick dolerite intrusion in contact with the granite, favoring hydrothermal alteration processes.

Iron and manganese

Iron concentrations in general are relatively low $(0.01$ to $4.5 \mathrm{mg} / \mathrm{L})$, as usually occurs in granitic aquifers, considering that mafic minerals are accessories in the lithologies. When mafic bodies appear as intrusions of dolerite in the granitic rock, iron content in water can increase. The normally neutral or slightly alkaline $\mathrm{pH}$ in the aquifer breaks the iron dissolution and transport. This statement is in accord to CPRM (2013) regional mapping, when confirms that higher levels of iron may occur only locally. It must be emphasized the inexistence of a positive correlation between iron and sulfate, indicating that oxidation of pyrite is not the main source for iron. The average concentration of iron in the study area is $0.31 \mathrm{mg} / \mathrm{L}$, and without the two higher values ( 2.04 and $4.5 \mathrm{mg} / \mathrm{L})$, it comes to $0.063 \mathrm{mg} / \mathrm{L}$.

Manganese follow the iron in most cases, having a total low concentration in the water. In some wells with greater concentrations of iron, an increase in the content manganese also occurs, as in well $16(\mathrm{Fe}=0.34 \mathrm{mg} / \mathrm{L} ; \mathrm{Mn}=0.22 \mathrm{mg} / \mathrm{L}), \mathrm{well} 10(\mathrm{Fe}=0.2 \mathrm{mg} / \mathrm{L} ; \mathrm{Mn}=0.15 \mathrm{mg} / \mathrm{L})$ and well $9(\mathrm{Fe}=4.5 \mathrm{mg} / \mathrm{L} ; \mathrm{Mn}=0.956 \mathrm{mg} / \mathrm{L})$. The average manganese in the study area is $0.071 \mathrm{mg} / \mathrm{L}$ and without its highest value $(0.956$ $\mathrm{mg} / \mathrm{L})$, it drops to $0.035 \mathrm{mg} / \mathrm{L}$.

\section{Nitrate}

The probable sources for nitrate are linked to external factors, such as domestic effluents and agriculture. All the water samples showed concentrations below the national potability limits $(44.3 \mathrm{mg} / \mathrm{L})$. The highest contents are related to wells 1, 26 and 37 (13.26 mg/L, 15.29 $\mathrm{mg} / \mathrm{L}$ and $14.99 \mathrm{mg} / \mathrm{L}$, respectively). In the well 1, the location suggests domestic effluents influence, in counterpart to wells 26 and 37 were agriculture activity is predominant in the area. The results also demonstrate that samples up to $2 \mathrm{mg} / \mathrm{L}$ of nitrate have direct influence of rainfall and organic matter decomposition. 


\section{Environmental ionic ration indicators}

The relationship between certain ions helps to provide information regarding the aquifer hydrogeochemistry, being useful to emphasize similarities between water and the lithologies that make up the aquifer. According to Schoeller (1963), the interval between $0.09-0.6$ for $\mathrm{rK}^{+} / \mathrm{Na}^{+}$is consistent with water circulating in granitic rocks and values $<1$ are indicative of intense potassium fixation by clays and/or consumption by vegetables reflecting, in this way, in a more sodium water. The results of the study area are in accordance with these statements, since the highest value found, for well 22 , is $0.440 \mathrm{mEq} / \mathrm{L}$ (Tab. 3).

Hem (1985) also estimates for rocks of granitic composition values between $0.25-0.33$ referring to the $\mathrm{Mg}^{2+} / \mathrm{Ca}^{2+}$ ratio. In the study area, granitic lithotypes occur predominantly, sometimes varying from syenites and monzonites, being natural, therefore, that the ratios demonstrate values consistent with or close to Hem statements. Some $\mathrm{Mg}^{2+} / \mathrm{Ca}^{2+}$ ratios are higher, approaching 1 and sometimes exceeding this value, however this is not due to high concentrations of magnesium (except for well 2), but to low concentrations of calcium, raising the ratio.

The $\mathrm{Cl}^{-} / \mathrm{HCO}_{3}{ }^{-}$ratio provides inputs on climatic conditions, rainfall regime, evaporation and presence of marine water. For the present study, the ratios were used in order to verify the mixture of continental groundwater with marine waters. Todd (2006) states that the average value of the $\mathrm{Cl}^{-} / \mathrm{HCO}_{3}{ }^{-}$ratio for waters that circulate in crystalline rocks without interference from sea water is 0.5 . Therefore, a considerable increase in this value, combined with the proximity to the ocean, may be indicative of a saline intrusion in the continental aquifer.

There is a predominance of bicarbonate waters in the study area as demonstrated by low $\mathrm{Cl}^{-} / \mathrm{HCO}_{3}{ }^{-}$ratios. According to Todd (2006), waters with initial salinization show results $>1.3$ and, with advanced salinization, $>6.6$. Wells 1 and 3 show ratio values $1<\mathrm{Cl}^{-} / \mathrm{HCO}_{3}{ }^{-}<1.3$, corresponding to continental waters. However, in well 14 the $\mathrm{Cl}^{-} / \mathrm{HCO}_{3}{ }^{-}$ratio is much higher $(2,545)$ suggesting marine waters. Sediments deposited under the ocean regime (lagoon deposit) and/or marine waters influence this local, as previously discussed.

Table 3 - Ionic rations indicators $(\mathrm{mEq} / \mathrm{L})$ for the studied wells. Asterisk $=$ No data 


\begin{tabular}{|c|c|c|c|}
\hline Well & $r K^{+} / \mathrm{Na}^{+}$ & $\mathrm{rMg}^{2+} / \mathrm{Ca}^{2+}$ & $\mathrm{rCl} / \mathrm{HCO}_{3}^{-}$ \\
\hline 1 & 0,128 & 0,922 & 1,443 \\
\hline 2 & 0,023 & 1,289 & 0,489 \\
\hline 3 & 0,205 & 2,105 & 1,031 \\
\hline 4 & 0,049 & 0,533 & 0,738 \\
\hline 5 & 0,166 & 1,685 & 0,206 \\
\hline 6 & 0,113 & 0,225 & * \\
\hline 7 & 0,128 & 0,374 & 0,390 \\
\hline 8 & * & * & * \\
\hline 9 & * & * & * \\
\hline 10 & N.D & 0,180 & 0,296 \\
\hline 11 & 0,044 & 0,960 & 0,117 \\
\hline 12 & 0,383 & 0,361 & 0,178 \\
\hline 13 & 0,353 & 0,105 & * \\
\hline 14 & 0,012 & 0,499 & 2,545 \\
\hline 15 & 0,003 & 1,391 & * \\
\hline 16 & 0,008 & 0,615 & * \\
\hline 17 & N.D & N.D & 0,390 \\
\hline 18 & N.D & N.D & 0,965 \\
\hline 19 & N.D & N.D & * \\
\hline 20 & N.D & N.D & $\star$ \\
\hline 21 & 0,402 & 0,359 & 0,111 \\
\hline 22 & 0,440 & 0,666 & 0,205 \\
\hline 23 & 0,173 & 1,066 & * \\
\hline 24 & 0,042 & 0,417 & * \\
\hline 25 & 0,040 & 0,181 & 0,064 \\
\hline 26 & 0,073 & N.D & 0,338 \\
\hline 27 & * & 0,815 & 0,042 \\
\hline 28 & * & * & 0,686 \\
\hline 29 & * & * & * \\
\hline 30 & 0,088 & 0,439 & * \\
\hline 31 & 0,110 & 0,863 & 0,368 \\
\hline 32 & 0,569 & 0,569 & * \\
\hline 33 & * & * & * \\
\hline 34 & 0,181 & N.D & 0,958 \\
\hline 35 & 0,115 & 0,550 & * \\
\hline 36 & 0,155 & 0,587 & 0,184 \\
\hline 37 & * & * & 0,294 \\
\hline 38 & 0,019 & 0,4 & * \\
\hline
\end{tabular}

Page 10/16 


\begin{tabular}{|llll|}
\hline 39 & 0,036 & 0,752 & $*$ \\
40 & 0,102 & 0,520 & 0,168 \\
\hline
\end{tabular}

\section{Groundwater chemical classification}

For a better understanding the chemical characteristics of groundwater in the Florianopolis metropolitan region the chemical compositions were plotted in a Piper trilinear diagram. Considering that not all the samples have a complete set of chemical analysis, 26 wells were plotted in the diagram. Alkalinity was used as a parameter in 5 wells, since the $\mathrm{pH}$ range in these wells is 6.2 to 6.74 .

In the study area, there is a clear predominance of sodium bicarbonate waters, while calcium bicarbonate waters are less frequent, followed in addition to mixed bicarbonate, mixed chloride, sodium chloride, calcium chloride, sodium mixed and calcium mixed (Fig. 8).

The predominance of bicarbonate waters is due to the hydrolysis of calcium carbonate that fills fractures in the crystalline rocks of the study region. The sodium and calcium terms, which are also dominant in the classification, show a geochemical signature consistent with granitic aquifers. Calcium-magnesium terms are restricted referring to some basic rocks as protoliths of the Águas Mornas Complex.

The hydrochemical groups are distributed randomly in the study area, without correlation with any spatial distribution. However, in a strip located from the north of the municipality of Palhoça to the west of the municipality of Águas Mornas, passing through Santo Amaro da Imperatriz, there is a predominance of sodium bicarbonate waters. The group of chloride waters also does not occur exclusive to any geographical sector. However, all of them are closer to the ocean.

\section{Conclusions}

Hydrogeological assessments show that fractured aquifers in the region, depending on the need for use and structural knowledge of the site, can be a viable alternative for obtaining water of good quality.

Wells located close to or on the intersection between lineaments proved to be more productive. Concerning the linear structures that occur in the area, the NW-SE orientation lineaments, in general, have greater water potential than the lineaments of NE-SW direction. However, this fact is not a rule due to the geological and structural complexity that can occur in fractured aquifers.

The area with the greatest productive potential in the study region are located in the north of the municipality of Palhoça, following a strip that includes the municipalities of Santo Amaro da Imperatriz and Águas Mornas. Regarding the lithologies, three of them (Serra do Tabuleiro Granite, São Pedro de Alcântara Granite and Águas Mornas Complex) stand out with greater water potential, showing average discharges higher than $17 \mathrm{~m}^{3} / \mathrm{h}$.

The hydrochemical characteristics of the region demonstrate, among the anions, bicarbonate is dominant and its presence is directly linked to the hydrolysis of calcium carbonate filling the fractures of the rocks. Cations appear in the proportion of $\mathrm{Na}^{+}>\mathrm{Ca}^{2+}>\mathrm{Mg}^{2+}>\mathrm{K}^{+}$, which reflects the weathering in granitic rocks, which occur widely distributed in the region.

The hydrochemical groups, in general, appear randomly distributed in the study area. However, occur one NE-SW direction strip that extends from the north of the municipality of Palhoça until west of Águas Mornas, where there is a predominance of sodium bicarbonate waters. Wells that contain chloride water are characteristic of being close to the ocean.

Water samples from wells with higher dissolved salts content are probably under influence of Quaternary marine sediments that cover the area or by direct impact due to marine intrusion, in conditions of overpumping.

\section{Declarations}

Funding: Not applicable

Conflicts of interest/Competing interests: Not applicable

Availability of data and material: Not applicable 
Code availability: Not applicable

Authors' contributions: Not applicable

\section{References}

Appelo CAJ, Postma D (2005) Geochemistry, Groundwater and Pollution (2ed.). Balkema, Rotterdam

Companhia de Pesquisa de Recursos Minerais (1997) Programa levantamentos geológicos básicos do Brasil, Florianópolis (folha SG.22-ZD-V) e Lagoa (folha SG.22-Z-D-VI). http://rigeo.cprm.gov.br/xmlui/bitstream/handle/doc/8736/Florianopolis_Lagoa.pdf? sequence=1\&isAllowed=y. Accessed 27 January 2021

Companhia de Pesquisa de Recursos Minerais (2011) Projeto Atlas Pluviométrico do Brasil.

https://www.cprm.gov.br/publique/media/hidrologia/mapas_publicacoes/atlas_pluviometrico_brasil/isoietas_totais_anuais_1977_2006.pdf Acessed 27 January 2021

Companhia de Pesquisa de Recursos Minerais (2013) Mapa hidrogeológico do Estado de Santa Catarina.

http://www.cprm.gov.br/publique/media/hidrologia/mapas_publicacoes/rel_mapa_hid_sc.pdf. Accessed 27 January 2021

Companhia de Pesquisa de Recursos Minerais (2014) Mapa geológico do Estado de Santa Catarina.

http://rigeo.cprm.gov.br/xmlui/bitstream/handle/doc/17996/mapa_geologico_santa_catarina.pdf?sequence=5\&isAllowed=y. Accessed 27 January 2021

Davis SN, DeWiest RJM (1966) Hydrogeology. John Wiley \& Sons, New York

Hem JD, Waring GS, White DE (1963) Date of geochemistry: chemical composition of subsurface waters. Geological Survey Professional Paper, Washington

Hem JD (1985) Study and interpretation of chemical characteristics of natural water. U.S Geological Survey Water-Supply Paper, Washington

Schoeller M (1962) Les Eaux Souterrains. Masson \& C. Editeurs, Paris

Todd DK (2006) Groundwater, hydrology. John Wiley, New York

WHO (2012) Environmental Health Criteria. World Health Organization, Geneva

\section{Figures}




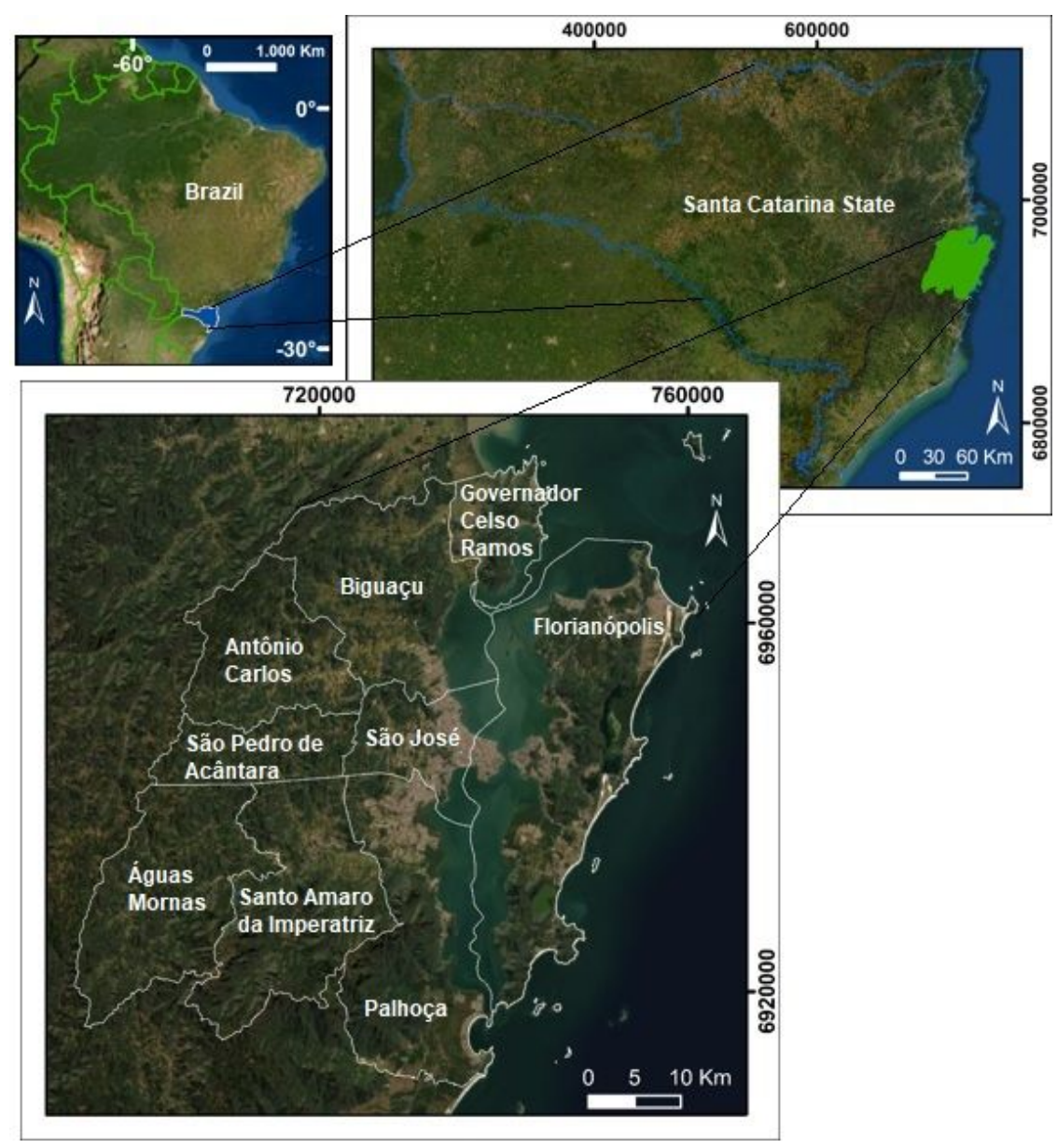

Figure 1

Location and municipalities in the study area 


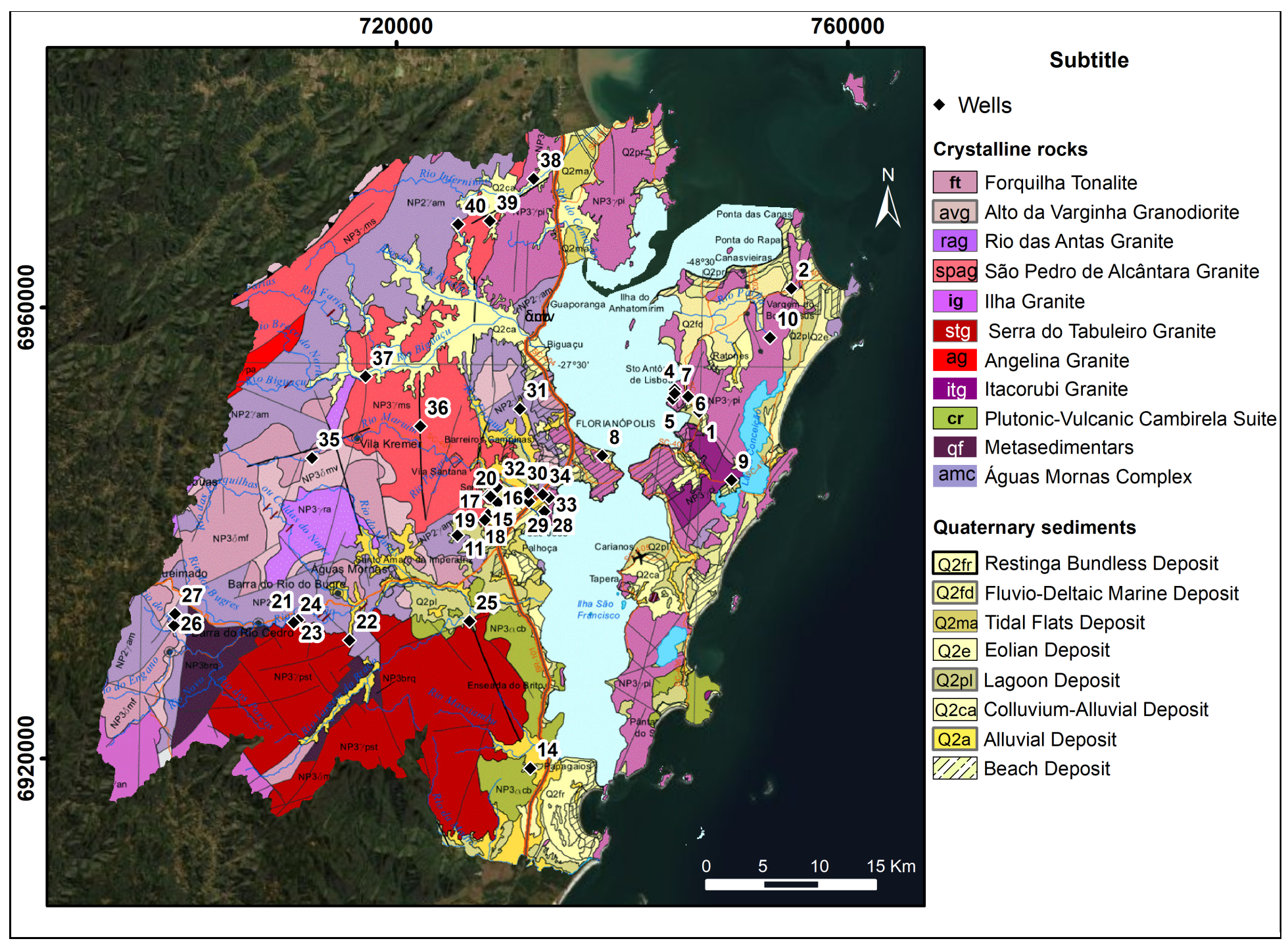

Figure 2

Geology of study area (after CPRM 2014) and location of tubular wells

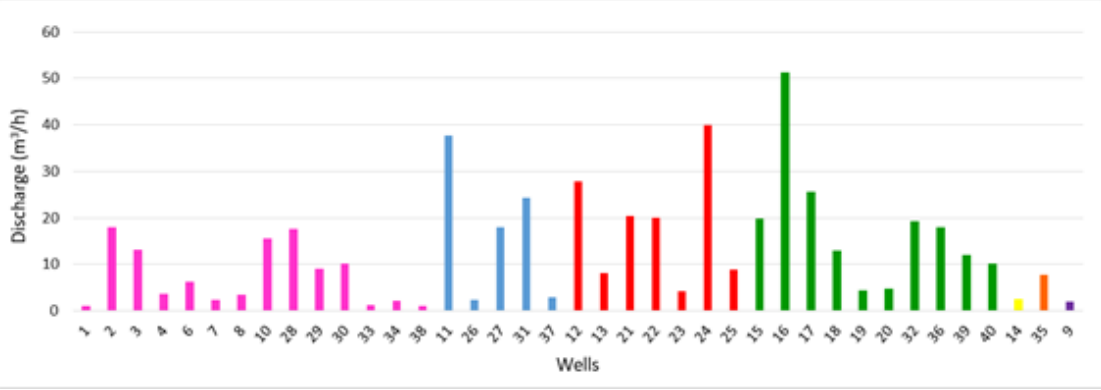

Figure 3

Discharges from wells by lithology. Pink: Ilha Granite; Blue: Águas Mornas Complex; Red: Serra do Tabuleiro Granite; Green: São Pedro de Alcântara Granite; Yellow: Plutonic-Vulcanic Cambirela Suite; Orange: Rio das Antas Granite/Forquilha Tonalite Purple: Itacomrubi Granite 


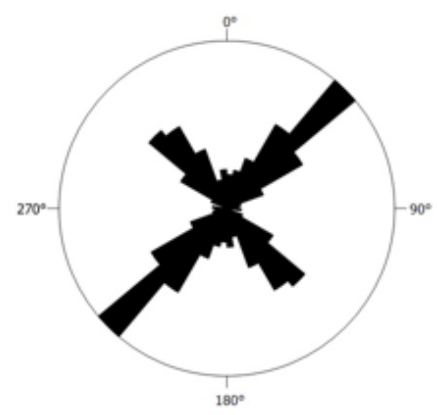

Figure 4

Rose diagram of the lineaments found around the wells in a $1.5 \mathrm{~km}$ radius showing predominance of NE-SW structures

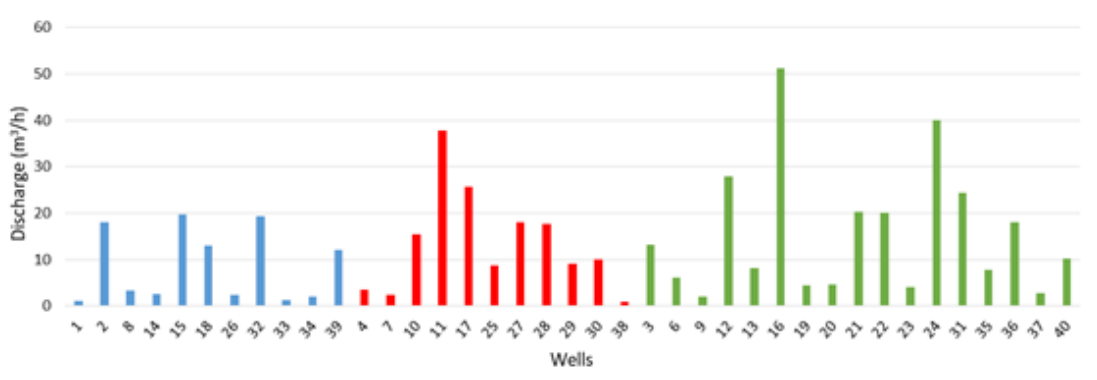

\section{Figure 5}

Main orientation of the linear structure from which the well captures water and discharge from the respective well. Blue = NE; Red: NW; Green: NE and NW
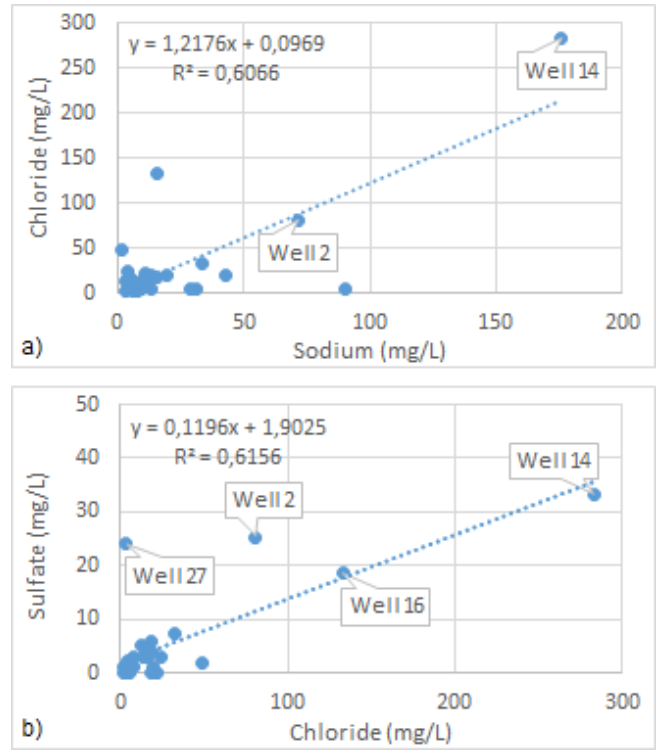

\section{Figure 6}

a) Positive correlation between sodium and chloride in wells 2 and 14 demonstrating that in these wells there is a contribution of ions from the quaternary sediments or a slight mixture with ocean waters; b) Positive correlation of sulfate with chloride with the exception of well 27 

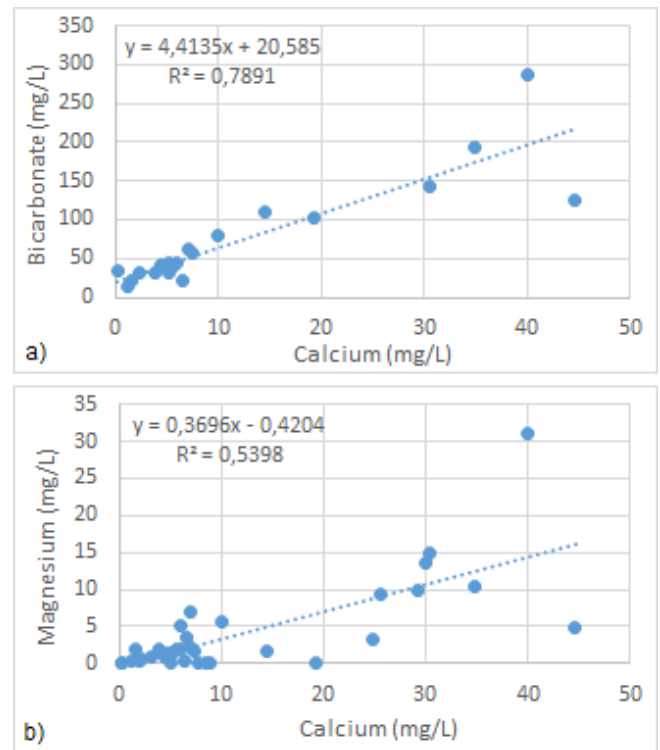

\section{Figure 7}

a) positive correlation between calcium and bicarbonate; b) positive correlation between calcium and magnesium

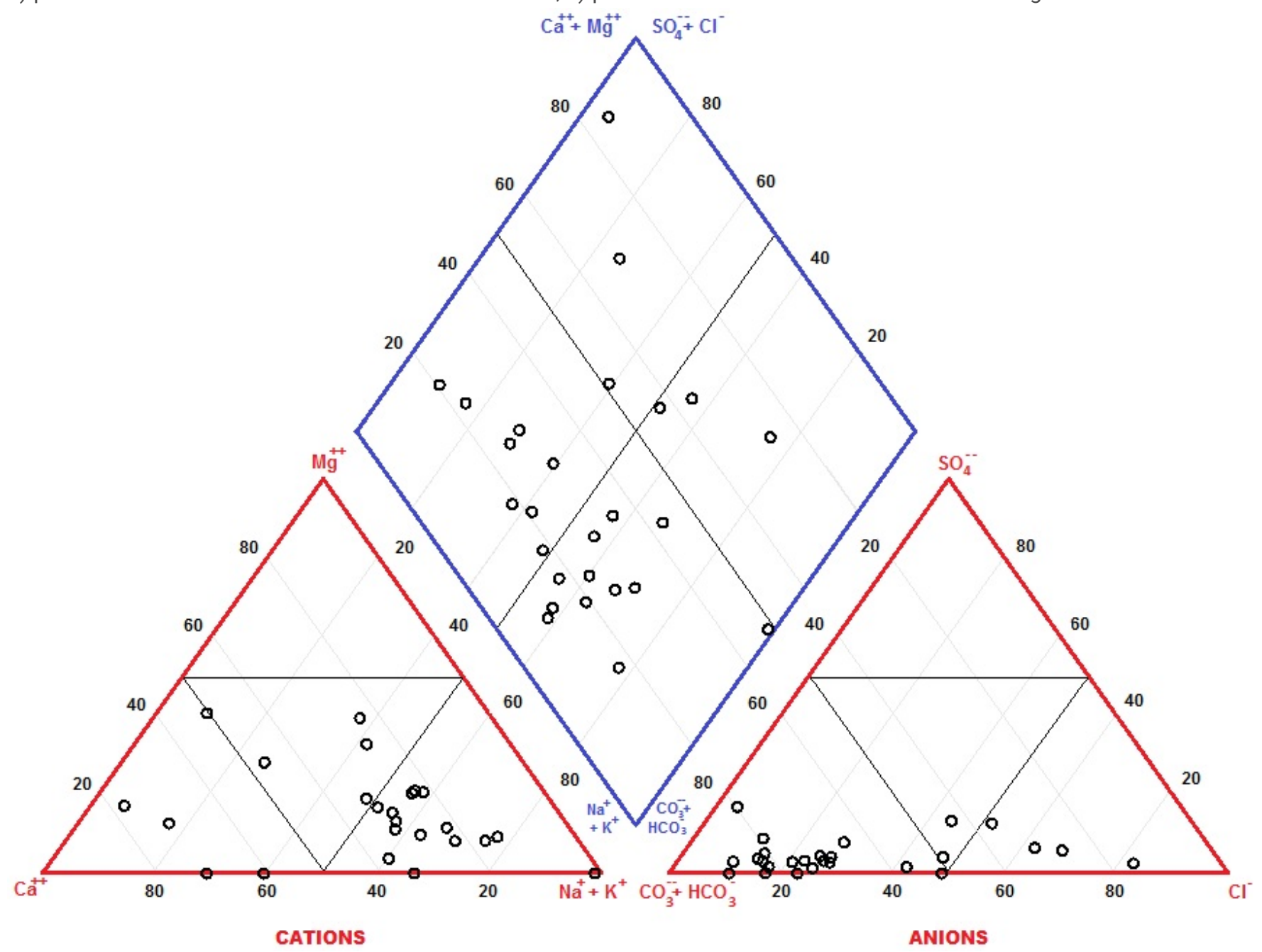

Figure 8

Groundwater classification of 26 according to Piper Diagram 